\title{
Transduced PEP-1-Grb7 Fusion Protein Suppressed LPS-induced COX-2 Expression
}

\author{
Jae Jin An, So Young Kim, Sun Hwa Lee, Dae Won Kim, Hea Jin Ryu, Seung Il Yeo, \\ Sang Ho Jang, Hyung Joo Kwon', Tae Yoon Kim², Sang Chul Lee ${ }^{3}$, Haryoung Poo ${ }^{3}$, \\ Sung-Woo Cho ${ }^{4}$, Kil Soo Lee, Jinseu Park, Won Sik Eum* and Soo Young Choi* \\ Department of Biomedical Science and Research Institute for Bioscience and Biotechnology, Hallym University, \\ Chunchon 200-702, Korea \\ ${ }^{1}$ Department of Microbiology, College of Medicine, Hallym University, Chunchon 200-702, Korea \\ ${ }^{2}$ Department of Dermatology, College of Medicine, Catholic University, Seoul 137-040, Korea \\ ${ }^{3}$ Systemic Proteomics Research Center, KRIBB, Taejeon 305-806, Korea \\ ${ }^{4}$ Department of Biochemistry and Molecular Biology, University of Ulsan College of Medicine, Seoul 138-736, Korea.
}

Received 11 September 2006, Accepted 2 October 2006

\begin{abstract}
Although the incidence and severity of atopic dermatitis (AD) is steadily increasing at an alarming rate, its pathogenic mechanisms remain poorly understood yet. Recently, we found that the expression of Grb7 protein was markedly decreased in AD patients using proteomic analysis. In the present study, human Grb7 gene was fused with PEP-1 peptide in a bacterial expression vector to produce a genetic in-frame PEP-1-Grb7 fusion protein. The expressed and purified PEP-1-Grb7 fusion proteins transduced efficiently into skin cells in a time- and dose-dependent manner when added exogenously in culture media. Once inside the cells, the transduced PEP-1-Grb7 protein was stable for $48 \mathrm{~h}$. In addition, transduced PEP-1-Grb7 fusion protein markedly increased cell viability in macrophage RAW 264.7 cells treated with LPS by inhibition of the COX-2 expression level. These results suggest that the PEP-1-Grb7 fusion protein can be used in protein therapy for inflammatory skin disorders, including AD.
\end{abstract}

Keywords: Atopic dermatitis (AD), COX-2, PEP-1-Grb7, Protein therapy, Protein transduction

\section{Introduction}

Atopic dermatitis (AD) is a common pruritic and chronically relapsing inflammatory skin disease with a steadily increasing

*To whom correspondence should be addressed.

Tel: 82-33-248-2112; Fax: 82-33-241-1463

E-mail: sychoi@hallym.ac.kr andwseum@hallym.ac.kr prevalence. Endogenous, as well as exogenous, factors play a role in the manifestation of $\mathrm{AD}$ disease. $\mathrm{AD}$ has a serious effect on patients, their families, and socioeconomic aspects of life (Homey et al., 2006). AD is a major public-health problem worldwide with lifetime prevalence of $10-20 \%$ in children, and a prevalence of $1-3 \%$ in adults (Schultz-Larsen and Hanifin, 2002). Wide variations in prevalence have been identified within countries inhabited by similar ethnic groups, suggesting that environmental factors determine the expression of $\mathrm{AD}$ (Williams et al., 1999).

Prostaglandins (PGs) are potent proinflammatory mediators derived form arachidonic acid metabolism by cyclooxygenase (COXs), and play an important role in modulating a number of pathophysiological conditions, including inflammatory and allergic immune response (Tilly et al., 2001). The two isoforms of COX enzymes have been well studied. COX-1 is constitutively expressed and plays an important role in maintaining the normal physiological function of cells, and COX-2 whose expression is markedly induced by a number of stimuli, including cytokines, during the inflammatory response (Smith and Dewitt, 1990; Carey et al., 2003; Vancheri et al., 2004).

Lipopolysaccharide (LPS) is the main component of endotoxin and is formed by a phosphoglycolipid that is covalently linked to a hydrophilic heteropolysaccharide (Rietschel et al., 1994). LPS arrests macrophage proliferation and activates them to produce proinflammatory factors, which play important roles in the immune response (Adams and Hamilton, 1984; Morrison and Ryan, 1987).

Eosinophils act as effectors in the inflammatory reactions of allergic diseases such as asthma, allergic rhinitis and AD, and in the chronic development of allergic inflammation 
(Gleich, 2000; Fugihara et al., 2002; Wong et al., 2002). Yoon et al. (2005) reported that the phosphorylation level of Grb7 was significantly higher in healthy donor eosinophils than in those from $\mathrm{AD}$ patients by comparative proteomic study (Yoon et al., 2005). Grb7 was originally isolated as an epidermal growth factor receptor-binding adaptor protein and soon after several other growth factor receptors and intracellular signaling molecules were reported to associated with Grb7 (Margolis et al., 1992; Han et al., 1997; Daly, 1998). However, the functional significance of these specific interactions is still not completely understood.

Recently, several small regions of proteins, called protein transduction domains (PTDs), have been developed to allow the delivery of exogenous protein into living cells. Up to the present, many researchers have demonstrated the successful delivery of full-length Tat fusion proteins by protein transduction technology (Wadia and Dowdy, 2002). We successfully transduced Tat-SOD directly into insulin-producing RINm-5F and pancreatic islet cells and transduced Tat-SOD by increased radical scavenger activity in the pancreas (Eum et al., 2004a). Recently, we showed that Tat-pyridoxal kinase (Tat-PK) and Tat-pyridoxal oxidase (Tat-PO) fusion protein was efficiently transduced into PC12 cells and catalytically active in the cells (Kim et al., 2005; Kim et al., 2006). Also, we transduced PEP-1-SOD into neuronal cells and across the blood-brain barrier which efficiently protected against ischemic insults and Tat- $\alpha$-synuclein fusion protein protects against oxidative stress in vitro and in vivo (Eum et al., 2004b; Choi et al., 2006).

In the present study, we designed the PEP-1-Grb7 fusion protein by genetic in-frame for transduction and showed that the PEP-1-Grb7 fusion protein can be directly transduced into skin cells, and that it can efficiently protect against LPSinduced cell death. Therefore, we suggest that PEP-1-Grb7 fusion protein would be useful as a potential therapeutic agent for inflammatory skin diseases.

\section{Materials and Methods}

Cloning and purification of PEP-1-Grb7 fusion proteins. Cells permeable with a native protein structure PEP-1-Grb7 fusion protein was expressed in E. coli and the expressed enzyme was purified and characterized as previously described (Eum et al., 2004b). The PEP-1 expression vector was constructed to express the PEP-1 peptides (KETWWETWWTEWSQPKKKRKV) as a fusion with human Grb7. First, two oligonucleotides (top strand) 5'-TATGAAA GAAACCTGGTGGGAAACCTGGTGGACCGAATGGTCTCAG CCGAAAAAAAAACGTAAAGTGC-3' and (bottom strand) 5'-TC GABCACTTTACGTTTTTTTTTCGGCTGAGACCATTCGGTC CACCAGGTTTCCCACCAGGTTTCTTTCC-3' were synthesized and annealed to generate a double-stranded oligonucleotide encoding the PEP-1 peptides. The double-stranded oligonucleotide was directly ligated into NdeI-XhoI digested pET-15b vector. Second, on the basis of the cDNA sequence of human Grb7, two primers were synthesized. The sense primer, 5'-CTCGAGATGGTCAACCCCAC
CGTGTTCTTC-3' contains an XhoI site, and the antisense primer, 5'-GGATCCTTATCGAGTTGTCCACAGTGAGC-3', contains a Bam HI restriction site. The resulting PCR products were digested with $\mathrm{XhoI}$ and BamHI, eluted (Invitek), ligated into TA-cloning vector (Promega) and pPEP-1 vector using T4 DNA ligase (Takara), and cloned in E. coli BL21(DE3) cells.

To produce the PEP-1-Grb7 fusion protein, the plasmid was transformed into $E$. coli $\mathrm{BL} 21(\mathrm{DE} 3)$ cells. The transformed bacterial cells were grown in $100 \mathrm{ml}$ of $\mathrm{LB}$ media at $37^{\circ} \mathrm{C}$ to a $\mathrm{OD}_{600}$ value of $0.5-1.0$ and induced with $0.5 \mathrm{mM}$ IPTG at $37^{\circ} \mathrm{C}$ for $3-4 \mathrm{~h}$. Harvested cells were lysed by sonication at $4^{\circ} \mathrm{C}$ in a binding buffer containing $5 \mathrm{mM}$ imidazole, $500 \mathrm{mM} \mathrm{NaCl}, 20 \mathrm{mM}$ Tris- $\mathrm{HCl}$ (pH 7.9). After centrifugation, the supernatant was immediately loaded onto a $\mathrm{Ni}^{2+}$-nitrilotriacetic acid Sepharose affinity column (Qiagen). After the column was washed with 10 volumes of a binding buffer and 6 volumes of a washing buffer $(35 \mathrm{mM}$ imidazole, $500 \mathrm{mM}$ $\mathrm{NaCl}$, and $20 \mathrm{mM}$ Tris- $\mathrm{HCl}, \mathrm{pH} 7.9$ ), the fusion protein was eluted with an eluting buffer $(0.5 \mathrm{M}$ imidazole, $500 \mathrm{mM} \mathrm{NaCl}, 20 \mathrm{mM}$ Tris- $\mathrm{HCl}, \mathrm{pH}$ 7.9). The fusion proteins were combined and the salts were removed using a PD10 column chromatography (Amersham). The protein concentration was estimated by the Bradford procedure using bovine serum albumin as a standard (Bradford, 1976).

Transduction of PEP-1-Grb7 into human fibroblast cells. The human skin fibroblast cells were cultured in Dulbecco's modified Eagle's medium (DMEM) containing $20 \mathrm{mM}$ HEPES/NaOH (pH 7.4), $5 \mathrm{mM} \mathrm{NaHCO}_{3}, 10 \%$ fetal bovine serum (FBS) and antibiotics $\left(100 \mu \mathrm{g} / \mathrm{ml}\right.$ streptomycin, $100 \mathrm{U} / \mathrm{ml}$ penicillin) at $37^{\circ} \mathrm{C}$ under a humidified condition of $95 \%$ air and $5 \% \mathrm{CO}_{2}$. For the transduction of PEP-1-Grb7, skin cells were grown to confluence on a 6-well plate. The culture medium was then replaced with $1 \mathrm{ml}$ of fresh solution. After skin cells were treated with various concentrations of PEP-1-Grb7 for $1 \mathrm{~h}$, the cells were then treated with trypsinEDTA and washed with phosphate-buffered saline (PBS). Thereafter the cells were harvested for the preparation of cell extracts to perform Western blot analysis.

The intracellular stability of transduced PEP-1-Grb7 fusion protein was estimated as follows: after fibroblast cells were treated with $5 \mu \mathrm{M}$ native PEP-1-Grb7 for $1 \mathrm{~h}$, the cells were washed and changed with a fresh culture medium to remove the PEP-1-Grb7 that was not transduced. Cells were then further incubated for $60 \mathrm{~h}$, followed by preparations of cell extracts for Western blot analysis.

Western blot analysis. The transduced PEP-1-Grb7 proteins on the polyacrylamide gel were electrophoretically transferred to a nitrocellulose membrane. The membrane was blocked in 5\% nonfat milk in Trisbuffered saline (TBS; $20 \mathrm{mM}$ Tris, $0.2 \mathrm{M} \mathrm{NaCl}, \mathrm{pH}$ 7.5) containing $0.05 \%$ Tween-20 (TBST) for $2 \mathrm{~h}$ and was then incubated for $1 \mathrm{~h}$ at room temperature with anti-histidine antibody (Santa Cruz Biotechnology; dilution $1: 400$ ) in TBST. After washing, the membrane was incubated for $1 \mathrm{~h}$ with a proper secondary antibody conjugated to horseradish peroxidase diluted $1: 10000$ in TBST. The membrane was incubated with a chemiluminescent substrate and exposed to Hyperfilm ECL (Amersham Biosciences).

Determination of COX-2 protein expression. Murine macrophage cell line RAW 264.7 was cultured in DMEM including $2 \mathrm{mM} \mathrm{L-}$ glutamine, $100 \mathrm{U} / \mathrm{ml}$ penicillin, $100 \mu \mathrm{g} / \mathrm{ml}$ streptomycin and $10 \%$ 
FBS. Macrophages were cultured in 6-well plates at $37^{\circ} \mathrm{C}$ in $95 \%$ air and $5 \% \mathrm{CO}_{2}$. Cells were washed with fresh medium and stimulated with $100 \mathrm{ng} / \mathrm{ml}$ LPS for $12 \mathrm{~h}$. Then, the expression of COX-2 protein levels were determined by Western blotting used anti-COX-2 antibody.

Effect of transduced PEP-1-Grb7 on cell viability. The biological activity of the transduced PEP-1-Grb7 fusion proteins was assessed by measuring the cell viability of RAW 264.7 cells that were treated with LPS $(50 \mu \mathrm{g} / \mathrm{ml})$ for $12 \mathrm{~h}$. The cells were then seeded into a 35 $\mathrm{mm}$ dish at $70 \%$ confluence. The cells were first pre-treated with PEP-1-Grb7 (1-5 $\mu \mathrm{M})$ for $1 \mathrm{~h}$, followed by the LPS. Cell viability was estimated with a colorimetric assay using 3-(4,5-dimethylthiazol2-yl)-2,5-dipheyltetrazolium bromide (MTT) staining.

\section{Results}

Construction and purification of PEP-1-Grb7 fusion protein. To generate a cell-permeable expression vector, PEP-1-Grb7 vector, a human Grb7 cDNA was subcloned into the pET-15b plasmid that had been reconstructed to contain the PEP-1 peptide. The PEP-1-Grb7 expression vector thus formed contained consecutive cDNA sequences encoding human Grb7, PEP-1 peptide (21 amino acids) and six histidine residues at the aminoterminus (Fig. 1). We also constructed the SOD expression vector to produce control Grb7 protein without PEP-1 transduction peptides (data not shown).

Following the induction of expression, the PEP-1-Grb7 fusion proteins were purified. Briefly, the fusion proteins were expressed in E. coli and the clarified cell extracts were loaded onto a $\mathrm{Ni}^{2+}$-nitrilotriacetic acid Sepharose affinity column under native conditions. Fusion protein containing fractions was combined and salts were removed using a PD10 column. The crude cell extracts obtained from E. coli and purified PEP-1Grb7 fusion proteins were electrophoresed in $8 \%$ SDS-PAGE. The expression and purification results are shown in Fig. 2A. The bands in lanes 2 and 3 show that the protein was highly expressed, and was a major component of the total soluble proteins. The expressed and purified proteins were further confirmed by Western blot analysis using an anti-rabbit polyhistidine antibody. PEP-1-Grb7 was detected at the corresponding bands in Fig. 2B.

\section{Transduction of PEP-1-Grb7 fusion protein into human} fibroblast cell. To evaluate the transduction ability of PEP-1Grb7 fusion protein, we analyzed the transduction of PEP-1Grb7 proteins by adding them to fibroblast culture media at 5 $\mu \mathrm{M}$ for various periods (5-60 $\mathrm{min})$, and then analyzed the transduced protein levels by Western blotting. The intracellular concentration of transduced PEP-1-Grb7 in cells was detected within $5 \mathrm{~min}$ and was seen to gradually increase at $60 \mathrm{~min}$ (Fig. 3A).

The dose-dependency of the transduction of PEP-1-Grb7 fusion proteins was further analyzed. Various concentrations (1-5 $\mu \mathrm{M})$ of PEP-1-Grb7 proteins were added to fibroblast in
(A)

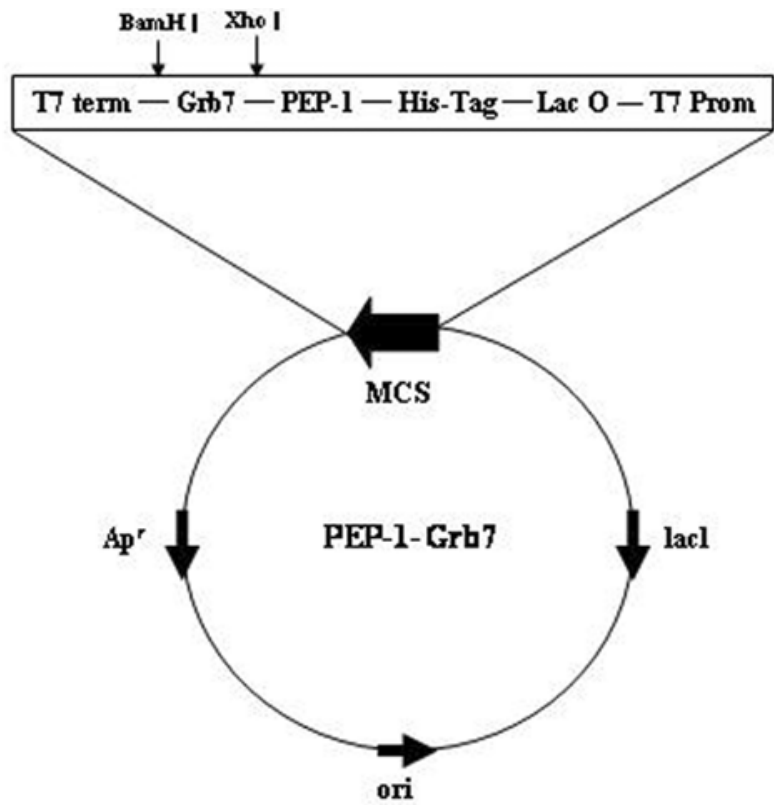

(B)

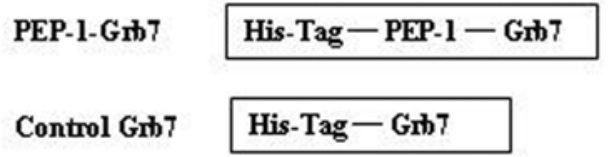

Fig. 1. The expression vector for PEP-1-Grb7 fusion protein. (A) Construction of the PEP-1-Grb7 expression vector system based on the vector pET-15b. Synthetic PEP-1 oligomer was cloned into the NdeI, XhoI sites, and human Grb7 cDNA was cloned into the XhoI, BamHI sites of pET-15b. (B) Diagram of expressed control Grb7 and PEP-1-Grb7 fusion proteins. The coding frame of human Grb7 is represented by an open box along with $6 \mathrm{His}$ and the PEP-1 peptide. The resulting vector was named pPEP-1Grb7. Expression was induced by adding IPTG

culture for $60 \mathrm{~min}$, and the levels of transduced proteins were measured by Western blotting. As shown in Fig. 3B, the levels of transduced proteins in fibroblast cells were concentrationdependently increased on increasing the amount of fusion protein in culture media.

The intracellular stability of transduced PEP-1-Grb7 into fibroblast cells is shown in Fig. 3C. The PEP-1-Grb7 fusion protein was added to the culture media of fibroblast cells at a concentration of $5 \mu \mathrm{M}$ for various time periods and the resulting levels of transduced protein were analyzed by Western blotting. The intracellular level of transduced PEP-1Grb7 fusion protein into cells was initially detected after $1 \mathrm{~h}$, and then declined gradually over the period of observation. However, significant levels of transduced Grb7 protein persisted in fibroblast cells for $48 \mathrm{~h}$.

Effect of PEP-1-Grb7 fusion protein on LPS-induced COX2 expression and cell viability. Macrophage plays crucial roles in the initiation and maintenance of inflammation. Since 
(A)

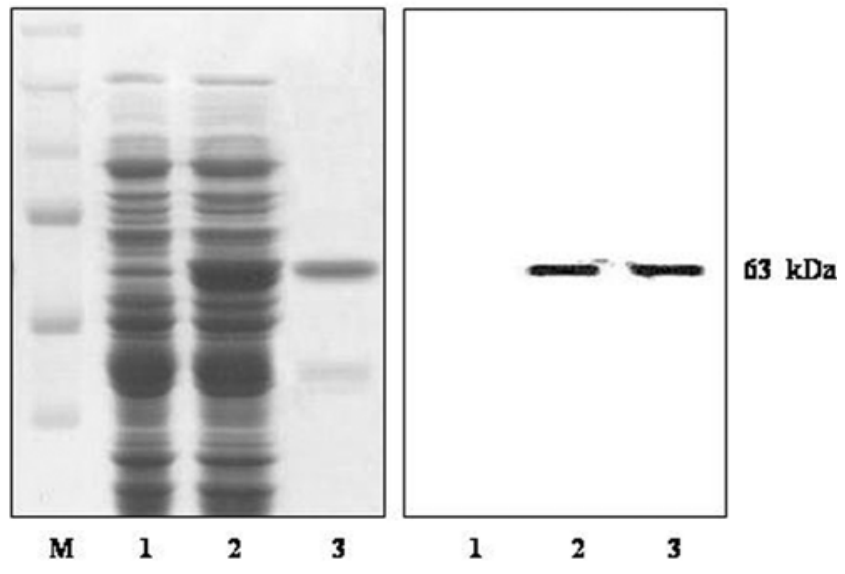

Fig. 2. Expression and purification of PEP-1-Grb7 fusion protein. Protein extracts of cells and purified fusion proteins were analyzed by $8 \%$ SDS-PAGE (A) and subjected to Western blot analysis with an anti-rabbit polyhistidine antibody (B). Lanes in A and B are as follows: lane 1, non-induced pPEP-1-Grb7; lane 2, induced pPEP-1-Grb7; lane 3, purified pPEP-1-Grb7.

(A)

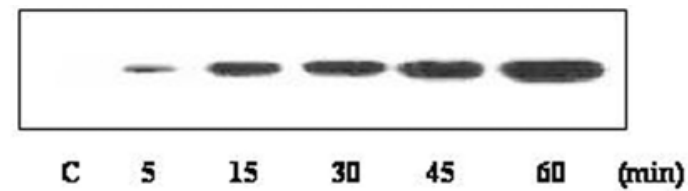

(B)

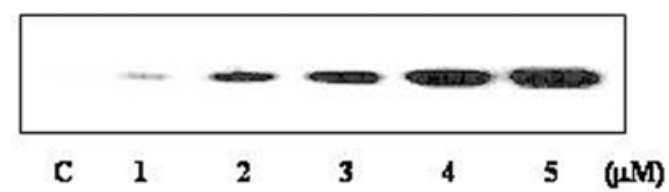

(C)

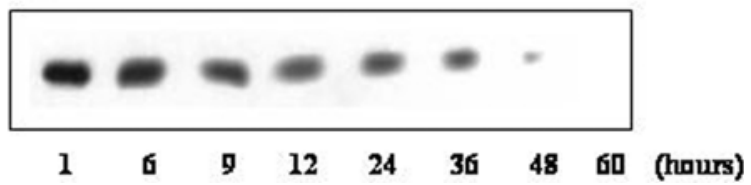

Fig. 3. Transduction of PEP-1-Grb7 fusion proteins. (A) $5 \mu \mathrm{M}$ PEP-1-Grb7 were added to the culture media for 5 60 min, (B) $1 \sim 5 \mu \mathrm{M}$ of PEP-1-Grb7 were added to the culture media for $1 \mathrm{~h}$, (C) cells pre-treated with $5 \mu \mathrm{M}$ PEP-1-Grb7 incubated for $1 \sim 60 \mathrm{~h}$, and analyzed by Western blot analysis.

the level of COX-2 is important to address the extent of inflammation and cell viability, the effect of PEP-1-Grb7 fusion protein on the inhibition of COX-2 expression and cell viability was investigated. RAW 264.7 cells were incubated for $12 \mathrm{~h}$ with LPS $(100 \mathrm{ng} / \mathrm{ml})$ in the presence or absence of various concentrations of PEP-1-Grb7 fusion protein. PEP-1Grb7 fusion protein suppressed LPS-induced COX-2 expression levels in RAW 264.7 cells in a dose-dependent manner. However, the control Grb7 protein did not suppressed LPSinduced COX-2 expression levels in the same conditions (Fig. 4). To determined whether transduced PEP-1-Grb7 fusion
(A)

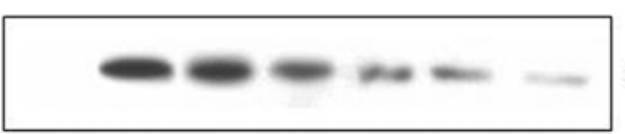
$\operatorname{cox}-2$

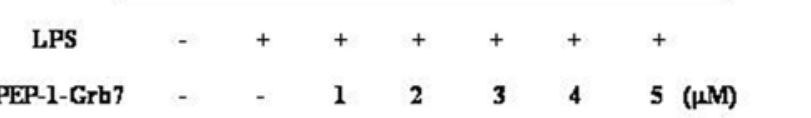

(B)

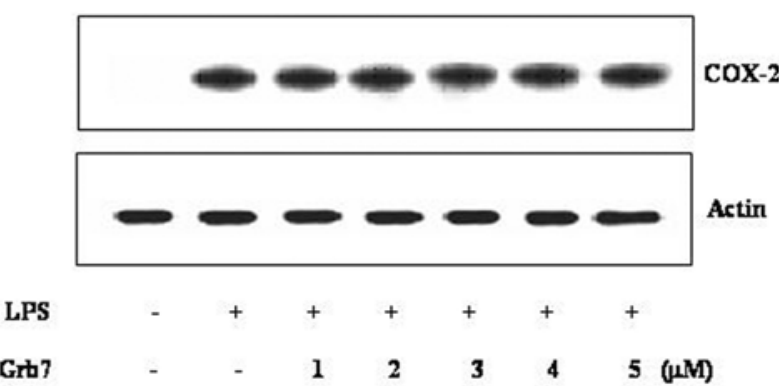

Fig. 4. Effect of transduced PEP-1-Grb7 on LPS-induced COX-2 protein expression. RAW 264.7 cells were pretreated with the PEP-1-Grb7 (A) and control Grb7 (B) for $1 \mathrm{~h}$ before incubation with LPS $(100 \mathrm{ng} / \mathrm{ml})$ for $12 \mathrm{~h}$. The cells were lysed and the lysates were analyzed by immunoblotting used anti-COX-2 antibody.

protein has cytotoxicity on RAW 264.7 cells, the cells were pretreated for $1 \mathrm{~h}$ with various concentrations $(1-5 \mu \mathrm{M})$ of PEP-1-Grb7 proteins and were incubated for $12 \mathrm{~h}$. No significant cytotoxicity of PEP-1-Grb7 fusion protein was determined in the cells (data not shown).

To determine whether the transduced PEP-1-Grb7 fusion proteins have a functional role in the cells, we tested the effects of transduced PEP-1-Grb7 fusion proteins on cell viability. As shown in Fig. 5, when the cells were exposed to LPS $(50 \mu \mathrm{g} / \mathrm{ml})$ for $12 \mathrm{~h}$ without PEP-1-Grb7 fusion protein, only $45-50 \%$ of the cells were viable. However, the viability of the cells pretreated with PEP-1-Grb7 fusion protein increased in a dose-dependent manner, reaching over $75 \%$ at the maximum concentration used. The increased viability of cells transduced with PEP-1-Grb7 fusion protein suggests that this fusion protein has a critical protective effect on cells against LPS-induced inflammation.

\section{Discussion}

Atopic dermatitis (AD) is characterized by epidermal alterations and dermal inflammatory infiltrating eosinophils. Although the etiology of chronic skin inflammatory disorders including psoriasis and $\mathrm{AD}$ is not clearly understood, many studies have shown that various pro-inflammatory enzymes/cytokines play an important role in these inflammatory diseases. In addition, activated eosinophils induce tissue injury and inflammation by 


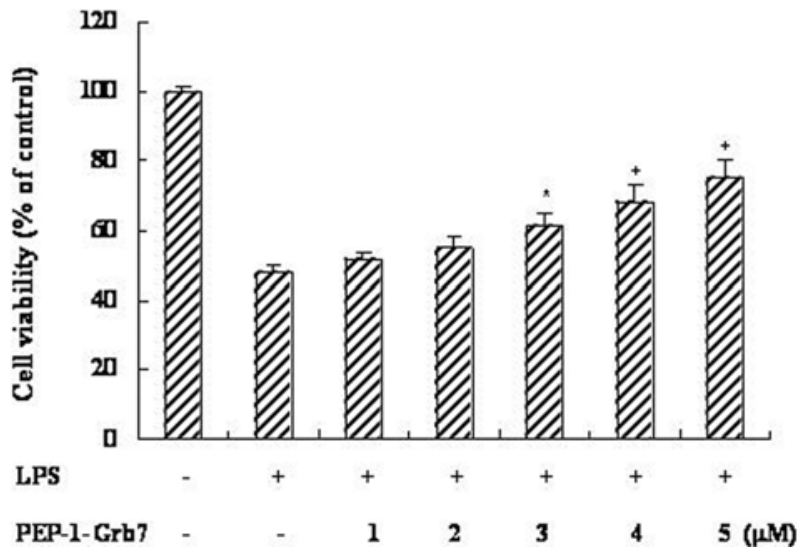

Fig. 5. Effect of transduced PEP-1-Grb7 on cell viability of RAW 264.7 cells. LPS $(50 \mu \mathrm{g} / \mathrm{ml})$ exposed cells pre-treated with $1 \sim 5 \mu \mathrm{M}$ PEP-1-Grb7 for $1 \mathrm{~h}$. Cell viabilities were estimated with a colorimetric assay using MTT. Each bar represents the mean \pm SEM obtained from five experiments. Asterisks and crosses denote statistical significance at $p<0.05$ and $p<0.01$, respectively. The statistical analysis was evaluated by Student's $t$-test.

secreting many inflammatory and pro-inflammatory mediators (Gleich, 2000). Thus, the interference of activity and/or suppression of these pro-inflammatory molecules may result in the attenuation of inflammatory skin diseases, and be an effective therapeutic strategy for preventing inflammatory diseases.

Grb7 is the founding member of a family of adaptor molecules that also include Grb10 and Grb14. Grb7 family members have been shown to interact with a variety of cell surface receptors and other signaling proteins (Daly, 1998; Han et al., 2001). Cell migration is critical for biological processes such as development, immune response, wound healing, and tumor metastasis. Initiation of cell migration involves detection of the gradients of soluble chemoattractants and/or immobilized environmental cues by cell surface receptors. These interactions are mediated by the $\mathrm{SH} 2$ domain of a Grb7 family member and a phosphor-tyrosine motif in the activated receptor/other signaling molecules. Many studies showed that Grb7 may play a role in the regulation of mammalian cell migration (Manser and Wood, 1990; Ooi et al., 1995; Han and Guan, 1999; Han et al., 2000). Recently, it was reported that the phosphorylation level of Grb7 was significantly higher in healthy donor eosinophils than in those from $\mathrm{AD}$ patients by comparative proteomic study and perhaps lead to the future development of new therapeutic targets for allergic diseases (Yoon et al., 2005). Although Grb7 has been considered potential as a therapeutic protein against inflammatory diseases, its inability to enter cells hinders its use for this purpose. Therefore, in an effort to deliver Grb7 protein to cells, we investigated the possibility of a protein transduction. Recently, the Morris group designed a 21-residue peptide carrier, PEP-1 (KETWWETWWTEWSQ PKKKRKV), which consists of three domains: a hydrophobic tryptophan rich motif (KETWWETWWTEW), a spacer (SQP), and a hydrophilic lysine-rich domain (KKKRKV). The hydrophobic domain is required for efficiently targeting the cell membrane and for hydrophobic interactions with proteins, whereas the hydrophilic domain is required to improve intracellular delivery. When mixed PEP-1 peptide and target protein (GFP, $\beta$-gal) were overlaid on cultured cells, it was found that the non-denatured target protein was transduced (Morris et al., 2001). In previous studies, we showed that PEP-1-SOD fusion protein was efficiently transduced into cells and skin tissue. Moreover, transduced PEP-1-SOD proved enzymatically and biologically active, and efficiently protected against neuronal cell death caused by transient forebrain ischemia (Eum et al., 2004b). Recently, we reported that PEP-1-SOD fusion protein can be directly transduced into neuronal cells across the blood-brain barrier and it can efficiently protect against paraquat-induced Parkinson's disease in the mouse model (Choi et al., 2006).

The PEP-1-Grb7 fusion protein was highly expressed as a major component of the total soluble proteins in cells and it was found to be nearly homogeneous and greater than $95 \%$ pure, as determined by a SDS-PAGE analysis. The expressed and purified PEP-1-Grb7 fusion proteins were confirmed by Western blot using an anti-rabbit polyhistidine antibody. Purified PEP-1-Grb7 fusion proteins were efficiently transduced into fibroblast cells in a time- and dose-dependent manner. Although the mechanism of transduction is unclear, Tat PTD fusion protein transduction is a major development in protein therapeutics. A wide variety of functional proteins have been successfully used to study intracellular function and transduction into cells and tissues (Wadia and Dowdy, 2002).

The intracellular stability of transduced PEP-1-Grb7 was significant with transduced protein persisting in fibroblast cells for $48 \mathrm{~h}$. A recent study by Morris et al. (2001) showed that PEP-1 peptide/GFP (green fluorescent protein, $30 \mathrm{kDa}$ ) or $\beta$-Gal ( $\beta$-galactosidase, $119 \mathrm{kDa})$ mixtures transduce into a human fibroblast cell line (HS-68) and into Cos-7 cells by incubating with PEP-1 peptide carrier and proteins (GFP or $\beta$ gal) for $30 \mathrm{~min}$ at $37^{\circ} \mathrm{C}$ (Morris et al., 2001). These differences in the time courses of transduction may depend on whether the target protein is fused with the PEP-1 vector or mixed with the PEP-1 peptide. Because of fusion with the PEP-1 vector, the conformation, polarity, and the molecular shape of a target protein might be altered, which improves the transduction of fusion proteins into cells.

To determine whether transduced PEP-1-Grb7 can play its biological role in cells, we tested the effects of transduced PEP-1-Grb7 on COX-2 expression level and cell viability under LPS exposure. COX-2 expression is markedly induced by a number of stimuli, including cytokines, during the inflammatory response (Vancheri et al., 2004; Carey et al., 2003; Smith and Dewitt, 1990). Nonsteroidal anti-inflammatory drugs inhibit COX, leading to a marked decrease in prostaglandin synthesis and inflammation (Simon, 1996). As shown in Fig. 4, transduced PEP-1-Grb7 fusion protein significantly suppressed LPS- 
induced COX-2 expression levels in RAW 264.7 cells in a dose-dependent manner. Also, the viability of LPS exposed cells was significantly increased when cells were pre-treated with PEP-1-Grb7 fusion proteins in a dose-dependent manner (Fig. 5). After the cells were exposed to LPS without PEP-1Grb7, only $45-50 \%$ of the RAW 264.7 cells were viable. However, transduced PEP-1-Grb7 protected against cell death by over $75 \%$. These results indicate that transduction of PEP1-Grb7 was definitively effective against LPS-induced cell death by inhibiting COX-2 expression.

In summary, we demonstrate for the first time that human Grb7 fused with PEP-1 peptide (PEP-1-Grb7) can be efficiently transduced into skin cells. In addition, PEP-1-Grb7 fusion protein significantly suppressed LPS-induced COX-2 expression and cell death. Although the detailed mechanism needs to be further elucidate, our success in the protein transduction of PEP-1-Grb7 may be beneficial against inflammatory skin disorders such as AD by topical application.

Acknowledgments This work was supported by the Next Generation Growth Engine Program Grant (F104AC01000206A0301-00210) from the Korean Science and Engineering Foundation and in part by a Regional Innovation Center (RIC) Grant from the Ministry of Commerce and Energy.

\section{References}

Adams, D. O. and Hamilton, T. A. (1984) The cell biology of macrophage activation. Annu. Rev. Immunol. 2, 283-318.

Bradford, M. A. (1976) A rapid and sensitive method for the quantification of microgram quantities of protein utilizing the principle of protein-dye binding. Anal. Biochem. 72, 248-254.

Carey, M. A., Germolec, D. R., Langenbach, R. and Zeldin, D. C. (2003) Cyclooxygenase enzymes in allergic inflammation and asthma. Prostaglandins Leukot. Essent. Fatty Acids 69, 157162.

Choi, H. S., An, J. J., Kim, S.Y., Lee, S. H., Kim, D. W., Yoo, K, Y., Won, M. H., Kang, T. C., Kwon, H. J., Kang, J. H., Cho, S. W., Kwon, O. S., Park, J., Eum, W. S. and Choi, S. Y. (2006) PEP-1-SOD fusion protein efficiently protects against paraquat-induced dopaminergic neuron damage in a Parkinson disease mouse model. Free Radic. Biol. Med. 41, 1058-1068.

Choi, H. S., Lee, S. H., Kim, S. Y., An, J. J., Hwang, S. I., Kim, D. W., Yoo, K. Y., Won, M. H., Kang, T. C., Kwon, H. J., Kang, J. H., Cho, S. W., Kwon, O. S., Choi, J. H., Park, J., Eum, W. S. and Choi, S. Y. (2006) Transduced Tat- $\alpha$-synuclein protects against oxidative stress in vitro and in vivo. $J$. Biochem. Mol. Biol. 39, 253-262.

Daly, R. J. (1998) The Grb7 family of signalling proteins. Cell Signal. 10, 613-618.

Eum, W. S., Choung, I. S., Li, M. Z., Kang, J. H., Kim, D. W., Park, J. Kwon, H. Y. and Choi, S. Y. (2004a) HIV-1 Tatmediated protein transduction of $\mathrm{Cu}, \mathrm{Zn}$-superoxide dismutase into pancreatic beta cells in vitro and in vivo. Free Radic. Biol. Med. 37, 339-349.

Eum, W. S., Kim, D. W., Hwang, I. K., Yoo, K. Y., Kang, T. C.,
Jang, S. H., Choi, H. S., Choi, S. H., Kim, Y. H., Kim, S. Y., Kwon, H. Y., Kang, J. H., Kwon, O. S., Cho, S. W., Lee, K. S., Park, J., Won, M. H. and Choi, S. Y. (2004b) In vivo protein transduction: Biologically active intact PEP-1superoxide dismutase fusion protein efficiently protects against ischemic insult. Free Radic. Biol. Med. 37, 1656-1669.

Fujihara, S., Ward, C., Dransfield, I., Hay, R. T., Uings, I. J., Hayes, B., Farrow, S. N., Haslett, C., Rossi, A. G. (2002) Inhibition of nuclear factor-kappaB activation un-masks the ability of TNF-alpha to induce human eosinophil apoptosis. Eur. J. Immunol. 32, 457-466.

Gleich, G. J. (2000) Mechanisms of eosinophil-associated inflammation. J. Allergy Clin. Immunol. 105, 651-663.

Han, D. C., Shen, T. L. and Guan, J. L. (2001) The Grb7 family proteins: structure, interactions with other signaling molecules and potential cellular functions. Oncogene 20, 6315-6321.

Han, D. C., Shen, T. L. and Guan, J. L. (2000) Role of Grb7 targeting to focal contacts and its phosphorylation by focal adhesion kinase in regulation of cell migration. J. Biol. Chem. 275, 28911-28917.

Han, D. C. and Guan, J. L. (1999) Association of focal adhesion kinase with Grb7 and its role in cell migration. J. Biol. Chem. 274, 24425-24430.

Homey, B., Steinhoff, M., Ruzicka, T. and Leung, D.Y.M. (2006) Cytokines and chemokines orchestrate atopic skin inflammation. J. Allergy Clin. Immunol. 118, 178-189.

Kim, S. Y., An, J. J., Kim, D. W., Choi, S. H., Lee, S. H., Hwang, S. I., Kwon, O. S., Kang, T. C., Won, M. H., Cho, S. W., Park, J., Eum, W. S., Lee, K. S. and Choi, S. Y. (2006) Tat-mediated protein transduction of human pyridoxine-5-P oxidase into PC12 cells. J. Biochem. Mol. Biol. 39, 76-83.

Kim, D. W., Kim, C. K., Choi, S. H., Choi, H. S., Kim, S. Y., An, J. J., Lee, S. R., Lee, S. H., Kwon, O. S., Kang, T. C., Won, M. H., Cho, Y. J., Cho, S. W., Kang, J. H., Kim, T. Y., Lee, K. S., Park, J., Eum, W. S. and Choi, S. Y. (2005) Tatmediated protein transduction of human brain pyridoxal kinase into PC12 cells. Biochimie 87, 481-487.

Margolis, B., Silvennoinen, O., Comoglio, F., Roonprapunt, C., Skolnik, E., Ullrich, A. and Schlessinger, J. (1992) Highefficiency expression/cloning of epidermal growth factorreceptor-binding proteins with Src homology 2 domains. Proc. Natl. Acad. Sci. USA 89, 8894-8898.

Manser, J. and Wood, W. B. (1990) Mutations affecting embryonic cell migrations in Caenorhabditis elegans. Dev. Genet. 11, 4964.

Morris, M. C., Depollier, J., Mery, J., Heitz, F. and Divita, G. (2001) A peptide carrier for the delivery of biologically active proteins into mammalian cells. Nat. Biotechnol. 19, 1173-1176.

Morrison, D. C. and Ryan, J. L. (1987) Endotoxins and disease mechanisms. Аnпи. Rev. Med. 38, 417-432.

Ooi, J., Yajnik, V., Immanuel, D., Gordon, M., Moskow, J. J., Buchberg, A. M. and Margolis, B. (1995) The cloning of Grb10 reveals a new family of $\mathrm{SH} 2$ domain proteins. Oncogene 10, 1621-1630.

Rietschel, E. T., Kirikae, T., Schade, F. U., Mamat, U., Schmidt, G., Loppnow, H., Ulmer, A. J., Zahringer, U., Seydel, U. and Di Padova, F. (1994) Bacterial endotoxin: molecular relationships and structure to activity and function. FASEB J. 8, 217-225.

Schultz-Larsen, F. and Hanifin, J. M. (2002) Epidemiology of 
atopic dermatitis. Immunol. Allergy Clin. North Am. 22, 1-24.

Simon, L. S. (1996) Actions and toxicity of nonsteroidal antiinflammatory drugs. Curr. Opin. Rheumatol. 8, 169-175.

Smith, W. L. and Dewit, D. L. (1990) Prostaglandin endoperoxide $\mathrm{H}$ synthase-1 and -2. Adv. Immunol. 62, 167-215.

Tilley, S. L., Coffman, T. M. and Koller, B. A. (2001) Mixed messages: modulation of inflammation and immune responses by prostaglandins and thromboxanes. J. Clin. Invest. 107, 1491-1495.

Vancheri, C., Mastruzzo, C., Sortino, M. A. and Crimi, N. (2004) The lung as a privileged site for the beneficial actions of PEG2. Trends Immunol. 25, 40-46.

Wadia, J. and Dowdy, S. F. (2002) Protein transduction technology. Curr. Opin. Biotechnol. 13, 52-56.

Williams, H., Robertson, C., Stewart, A., Ait-Khaled, N., Anabwani, G., Anderson, R., Asher, I., Beasley, R., Bjorksten,
B., Burr, M., Clayton, T., Crane, J., Ellwood, P., Keil, U., Lai, C., Mallol, J., Martinez, F., Mitchell, E., Montefort, S., Pearce, N., Shah, J., Sibbald, B., Strachan, D., von Mutius, E. and Weilland, S. K. (1999) Worldwide variations in the prevalence of symptoms of atopic eczema in the international study of asthma and allergies in childhood. J. Allergy Clin. Immunol. 103, 125-138.

Wong, C. K., Zhang, J. P., Ip, W. K. and Lam, C. W. (2002) Activation of p38 mitogen-activated protein kinase and nuclear factor-kappaB in tumour necrosis factor-induced eotaxin release of human eosinophils. Clin. Exp. Immunol. 128, 483-489.

Yoon, S. W., Kim, T. Y., Sung, M. H., Kim, C. J. and Poo, H. (2005) Comparative proteomic analysis of peripheral blood eosinophils from healthy donors and atopic dermatitis patients with eosinophilia. Proteomics 5, 1987-1995. 